\title{
Evidence of glucagon biosynthesis involving protein intermediates in rat salivary glands
}

\author{
A. Perez Castillo ${ }^{1}$ and E. Blazquez ${ }^{2}$ \\ ${ }^{1}$ Department Experimental Endocrinology, Instituto G. Marañón. Consejo Superior Investigaciones Científicas, Madrid and \\ ${ }^{2}$ Department of Physiology, Faculty of Medicine, University of Salamanca, Salamanca, Spain
}

\begin{abstract}
Summary. In an attempt to determine the ability of rat submaxillary glands to synthesise glucagon via protein intermediates, isolated cells from these glands were incubated in vitro with ${ }^{3} \mathrm{H}$-L-tryptophan and the acid-ethanol extracts of the cells were purified on Bio-Gel P-30 columns. Aliquots of the eluates were incubated with a C-terminal glucagon antiserum $(30 \mathrm{~K})$ and the radioactivity bound to the glucagon antibody appeared to be distributed among proteins of Molecular weight $>40.14$ and $3.5 \mathrm{Kdaltons}$. A similar elution pattern was obtained in the presence of urea $(7 \mathrm{~mol} / \mathrm{l})$ and guanidine hydrochloride $(6 \mathrm{~mol} / \mathrm{l})$. To determine the molecular weight of the immunoreactive material eluting before the 3.5 Kdalton polypeptide, aliquots of the cell extracts were immunoprecipitated and analysed by sodium dodecyl sulphate polyacryl-
\end{abstract}

amide gel electrophoresis. Polypeptides of 125.8, 63.1, 42.6 and $14.4 \mathrm{Kdaltons}$ were obtained. These polypeptides incorporate more radioactive tryptophan with increase in the time of incubation. Pulse-chase experiments with unlabelled tryptophan, cycloheximide-treatment of isolated cells and limited tryptic digestion of the larger glucagon immunoreactive component, transform it into a $3.5 \mathrm{Kdalton}$ polypeptide with immunological characteristics indistinguishable from pancreatic glucagon. These results suggest that the larger molecule contains glucagon and thus may serve as a precursor or an intermediate of extrapancreatic glucagon biosynthesis.

Key words: Glucagon biosynthesis, protein intermediates, rat submaxillary glands.
Our knowledge concerning the location of cells that produce and secrete polypeptide hormones has changed rapidly during the last few years. Gastrointestinal hormones have been detected in unforeseen locations [1] and peptides of neural origin have been found in pancreatic and gastrointestinal endocrine cells [2]. Glucagon, a hormone previously considered to be exclusively a product of pancreatic islets, has recently been detected in several extrapancreatic locations [3-6], where it could represent synthesised hormone, trapped or stored as an aggregate. However, cells similar to pancreatic A cells have been identified in the stomach [7,8], where large amounts of immunoreactive glucagon is released in response to specific stimuli [9-11]. Demonstration of active hormonal biosynthesis could offer conclusive evidence for the existence of extrapancreatic glucagon. In previous reports we have described that isolated cells of human [12] and rat submaxillary glands [5] incorporate ${ }^{3} \mathrm{H}$-L-tryptophan into a 3,500 dalton polypeptide with specific immune reaction with a C-terminal glucagon antiserum, suggesting that salivary glands actively synthesise glucagon rather than selectively trap or store this hormone. Therefore, the present study was designed in order to determine the ability of isolated rat submaxillary gland cells to synthesise glu- cagon, with special regard to defining the different forms of immunoreactive glucagon and the probable precursor-product relationship.

\section{Material and methods}

\section{Animals}

Female Wistar rats, weight $200-250$ g, were housed under controlled conditions of light and temperature and were fed a standard diet ad libitum (fat $3.8 \%$, carbohydrates $49.5 \%$, protein $21.4 \%$ ).

\section{Preparation and incubation of isolated cells from rat submaxillary glands}

After overnight starvation, rats were lightly anaesthetised with ether and the submaxillary glands removed. The glandular tissue was minced with scissors and incubated with Krebs-Ringer bicarbonate buffer (pH 7.4), and collagenase (1 mg/100 mg wet tissue; Type I, Sigma Chemicals, St. Louis, Mo, USA) for $8 \mathrm{~min}$. The final suspension revealed predominantly free cells, which were $95 \%$ viable as judged by their ability to exclude $0.5 \%$ Trypan blue in the absence of albu$\min$.

As controls for the biosynthesis of glucagon by cells of salivary glands, isolated hepatocytes prepared from overnight-fasted rats were used. Animals were lightly anaesthetised with ether, the abdomen opened through a wide incision and the portal vein exposed and cannulated. The liver was then perfused with $120 \mathrm{ml}$ of calcium and mag- 
nesium-free Krebs-Ringer bicarbonate buffer ( $\mathrm{pH} 7.4$ ) for $4 \mathrm{~min}$. Another $150 \mathrm{ml}$ of perfusion media containing $40 \mathrm{mg}$ of collagenase (Type I, Sigma), was infused into the liver for $5 \mathrm{~min}$. The digested liver was filtered, and the cells centifuged at $50 \mathrm{~g}$ for $2 \mathrm{~min}$. The suspension revealed predominantly free hepatocytes, which were $85 \%$ viable as judged by their ability to exclude $0.5 \%$ Trypan blue in the absence of albumin. All procedures with isolated cells were carried out in plastic laboratory ware. Subsequently, isolated cells $\left(1 \times 10^{6} / \mathrm{ml}\right)$ were incubated with Krebs-Ringer bicarbonate ( $\mathrm{pH} \mathrm{7.4)} \mathrm{enriched} \mathrm{with} \mathrm{bovine}$ serum albumin (BSA; $0.15 \mathrm{mmol} / 1)$ glucose $(5.5 \mathrm{mmol} / 1), 25 \mu \mathrm{Ci} / \mathrm{ml}$ of ${ }^{3} \mathrm{H}$-L-tryptophan $(6 \mathrm{Ci} / \mathrm{mmol}$; Amersham International, Bucks, UK) and apronitin $(1,000 \mathrm{KIU} / \mathrm{ml}$; FBA Pharmaceuticals, New York, USA) in an atmosphere of $95 \% \mathrm{O}_{2}$ and $5 \% \mathrm{CO}_{2}$ for 2 or 4 h. At the end of the incubation periods, $1 \mathrm{mg}$ of unlabelled tryptophan was added and the cells were homogenised in their own incubation medium, precipitated with trichloroacetic acid (10\% final concentration) and the sediment extracted in an acid-alcohol solution (ethanol: distilled water: $\mathrm{HCl}, 75: 23.2: 1.8$; by vol). Acid alcohol extracts were lyophilised, resuspended and purified futher by column chromatography.

\section{Pulse-chase incubation and cycloheximide-treatment of rat submaxillary gland isolated cells}

Isolated cells $\left(2 \times 10^{6} / \mathrm{ml}\right)$ were incubated for $2 \mathrm{~h}$ at $37^{\circ} \mathrm{C}$ in $2 \mathrm{ml}$ of Krebs-Ringer bicarbonate buffer (pH 7.4), containing BSA $(0.15 \mathrm{mmol} / 1$; Sigma $)$, glucose $(5.5 \mathrm{mmol} / 1)$ and ${ }^{3} \mathrm{H}-\mathrm{L}-\mathrm{tryptophan}$ $(25 \mu \mathrm{Ci} / \mathrm{ml})$ in an atomosphere of $95 \% \mathrm{O}_{2}$ and $5 \% \mathrm{CO}_{2}$. At the end of this incubation period, one half of the cell suspension was extracted with acid-ethanol and chromatographed on a Bio-Gel P-30 column. (Bio-Rad Laboratories, Richmond, California, USA) The second half of the cell suspension was centrifuged at $50 \mathrm{~g}$ for $1 \mathrm{~min}$ and the sediment resuspended in $1 \mathrm{ml}$ of Krebs-Ringer bicarbonate buffer (pH 7.4), containing BSA $(0.15 \mathrm{mmol} / \mathrm{l})$, glucose $(5.5 \mathrm{mmol} / 1)$ and unlabelled tryptophan $(1 \mathrm{mg} / \mathrm{ml})$ and incubated for $2 \mathrm{~h}$. At the end of this second incubation period, the hormonal components of the cell suspension were extracted as cited above and further purified on the same Bio-Gel P-30 column. When the isolated cells were treated with cycloheximide, the procedure followed in the first incubation period was the same as in the pulse-chase experiments with unlabelled tryptophan. At the end of this incubation period, one half of the cell suspension was extracted with acid-ethanol and chromatographied on Bio-Gel P-30 column. The second half of the cell suspension was incubated for $2 \mathrm{~h}$ with cycloheximide $(0.35 \mathrm{mmol} / \mathrm{l})$ and the hormonal components were then extracted as described above and further purified on the same Bio-Gel P-30 column.

\section{Gel filtration column chromatography}

Aliquots $(0.5 \mathrm{ml})$ of the acid-ethanol extracts, obtained as described above, were chromatographed on Bio-Gel P-30 columns $(1 \times 60 \mathrm{~cm})$. The columns were eluted with glycine buffer $(0.2 \mathrm{~mol} / 1, \mathrm{pH} 8.8)$ containing BSA $(0,04 \mathrm{mmol} / 1)$ and sheep serum $(1 \%)$ or Tris- $\mathrm{HCl}$ $(10 \mathrm{mmol} / \mathrm{l}$, pH 8.5$)$ with urea $(7 \mathrm{~mol} / 1)$ or Tris- $\mathrm{HCl}(10 \mathrm{mmol} / \mathrm{l}$, $\mathrm{pH} 8.5)$ with guanidine $\mathrm{HCl}(6 \mathrm{~mol} / \mathrm{l})$, and $1 \mathrm{ml}$ fractions were collected.

\section{Immunoprecipitation studies}

Eluates obtained from the columns equilibrated with glycine buffer $(0.2 \mathrm{~mol} / \mathrm{l}, \mathrm{pH} 8.8)$ plus BSA $(0.04 \mathrm{mmol} / \mathrm{l})$ and sheep serum $(1 \%)$, were taken for measurements of immunoreactivity with a $\mathrm{C}$-terminal glucagon antiserum $(30 \mathrm{~K})$ generously donated by Dr. R. H. Unger (Dallas, Texas, USA). Subsequently, aliquots $(0.4 \mathrm{ml})$ of the eluates were pre-incubated for $1 \mathrm{~h}$ at $37^{\circ} \mathrm{C}$ with $30 \mathrm{~K}$ antiserum $(0.1 \mathrm{ml}$; $1 / 10,000$ final dilution) and apronitin $(0.1 \mathrm{ml} ; 1,000 \mathrm{KIU})$ containing rabbit serum $\left(1 / 100\right.$ final dilution) and then incubated for $48 \mathrm{~h}$ at $4^{\circ} \mathrm{C}$ in the presence of a goat anti-rabbit $\gamma$-globulin precipitating antibody $(0.1 \mathrm{ml} ; 1 / 10-1 / 5$ final dilution depending on the batch used; Antibodies Incorporated, Davis, California, USA). The samples were centrifuged

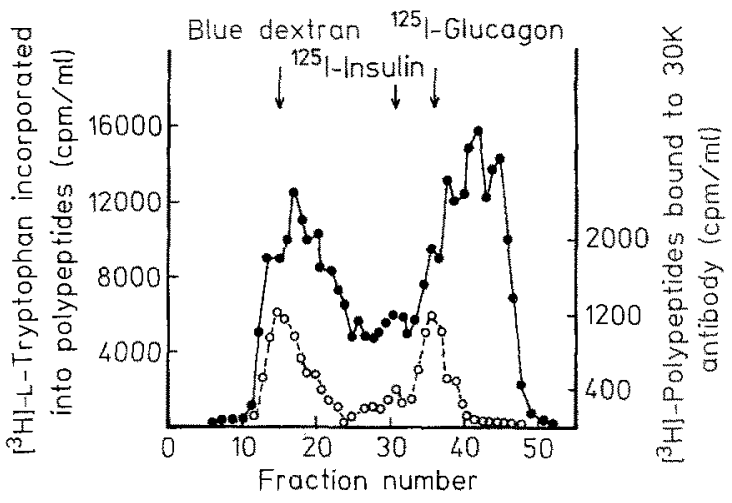

Fig. 1. (- - gel filtration profile of ${ }^{3} \mathrm{H}$-L-tryptophan incorporated into proteins from isolated cells of rat submaxillary glands. (O--O) profile of the specific immune reaction with a C-terminal glucagon antiserum $(30 \mathrm{~K})$. Both are representative of five different experiments

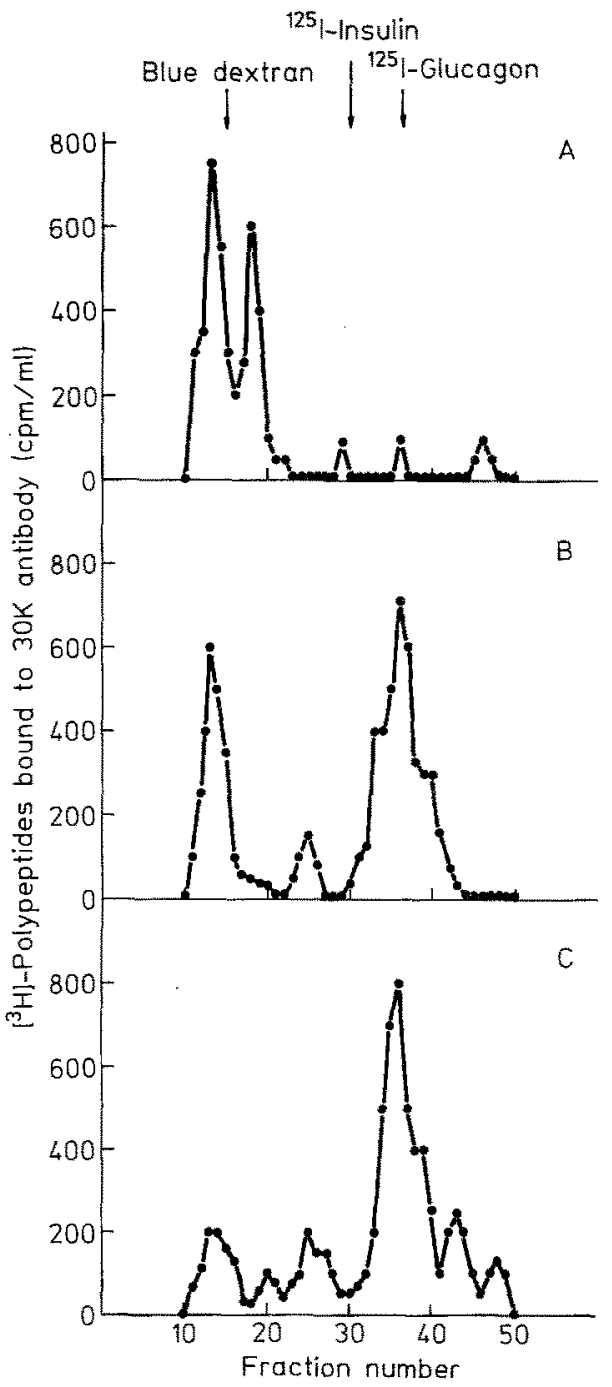

Fig. 2 A-C. A, B gel filtration profiles of ${ }^{3} \mathrm{H}$-L-tryptophan incorporated into proteins with specific immune reaction with a $\mathrm{C}$-terminal glucagon antiserum $(30 \mathrm{~K})$, from isolated cells of rat submaxillary glands after 2 or $4 \mathrm{~h}$ of incubation, respectively. $\mathrm{C}$ gel filtration profile after treatment of the larger glucagon immunoreactive peak $(A$, fractions 12-15) with trypsin. Chromatographic profiles are representative of four different experiments using the same Bio-Gel P-30 column 

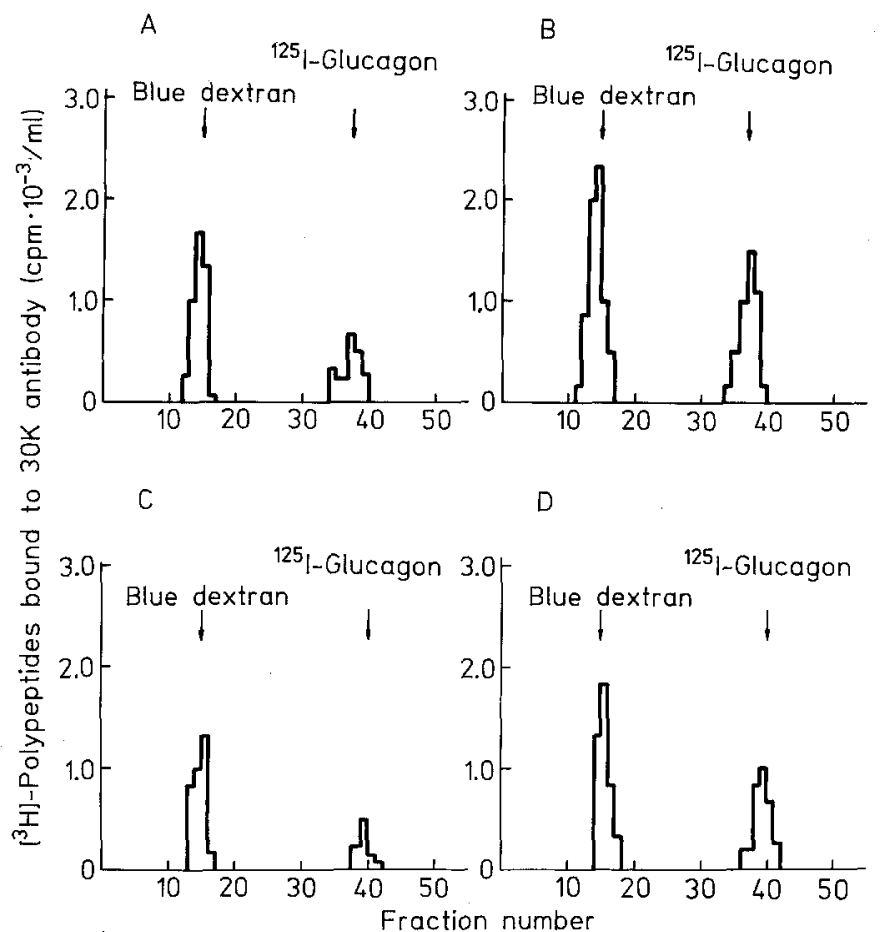

Fig. 3 A-D. Gel filtration profiles of ${ }^{3} \mathrm{H}$-L-tryptophan incorporation into proteins showing specific immune reaction with a $\mathrm{C}$-terminal glucagon antiserum from isolated cells of rat submaxillary glands. A, B chromatographic fractionation on a Bio-Gel P-30 column eluted with Tris- $\mathrm{HCl}(10 \mathrm{mmol} / 1, \mathrm{pH} 8.5)$ containing urea $(7 \mathrm{~mol} / \mathrm{l})$. C, D Chromatographic fractionation on a Bio-Gel P-30 column eluted with Tris- $\mathrm{HCl}(10 \mathrm{mmol} / 1, \mathrm{pH} 8.5)$ containing guanidine hydrochloride $(6 \mathrm{~mol} / \mathrm{l})$. A, C After 2 -h incubation; B, D After 4-h incubation. Chromatographic profiles are representative of four different experiments using the same Bio-Gel P-30 column

for $5 \mathrm{~min}$ at $1,500 \mathrm{~g}$ and the precipitate was solubilised with $\mathrm{NaOH}$ $(0.01 \mathrm{~mol} / \mathrm{l})$, mixed with $10 \mathrm{ml}$ of scintillation fluid and counted in a well-type counter (Beckman Instruments, Palo Alto, California, USA). Similar results were obtained using a second C-terminal glucagon antiserum (BBB) kindly donated by Dr. PP. Foà (Detroit, Michigan, USA).

When cell extracts were fractionated on sodium dodecyl sulphate PAGE or chromatographed on Bio-Gel P-30 columns with urea $(7 \mathrm{~mol} / \mathrm{l})$ or guanidine $\mathrm{HCl}(6 \mathrm{~mol} / \mathrm{l})$, aliquots $(0.5 \mathrm{ml})$ were immunoprecipitated with glucagon antiserum and a goat anti-rabbit $\gamma$-globulin, as cited above. The resulting precipitate was washed twice with glycine buffer $(0.2 \mathrm{~mol} / 1, \mathrm{pH} 8.8)$ containing BSA $(0.04 \mathrm{mmol} / \mathrm{l})$ and sheep serum $(1 \%)$ and then solubilised with $0.15 \mathrm{ml}$ of $\mathrm{HCl}(0.1 \mathrm{~mol} /$ 1). The radioactive peptides present in this preparation were analysed either by sodium dodecyl sulphate PAGE or by chromatographic fractionation on Bio-Gel P-30 column eluted with Tris- $\mathrm{HCl}$ $(10 \mathrm{mmol} / \mathrm{l}, \mathrm{pH} 8.5)$, containing urea $(7 \mathrm{~mol} / \mathrm{l})$ or guanidine $\mathrm{HCl}$ $(6 \mathrm{~mol} / 1)$.

\section{Polyacrilamide disc gel electrophoresis}

Samples obtained after immunoprecipitation of the cell extracts, as cited above, were analysed by sodium dodecyl sulphate $(0.1 \%)$ PAGE [13] in $8 \%$ gels. Standard molecular weight markers ( $\beta$-galactosidase, BSA, IgG light and heavy chains, ovoalbumin and cytochrome C) were electrophoresed simultaneously in a separate gel and stained with Coomassie Blue. Unstained gels containing the experimental samples were cut into $2 \mathrm{~mm}$ sections. Each section was solubilised with Soluene-350 (Packard Instruments, Downers Grove, Illinois, USA) and counted in a $\beta$-counter (Beckman Instruments).

\section{Trypsin treatment of the large glucagon immunoreactive peak}

To assess the effect of proteolysis on the large glucagon immunoreactive molecule, eluates of the larger glucagon immunoreactive peak (Fig 2A; fractions 12-15) were mixed and lyophilised. The lyophilised powder was resuspended in $1.5 \mathrm{ml}$ of glycine buffer $(0.2 \mathrm{~mol} / \mathrm{l}$, $\mathrm{pH} 8.8$ ) and incubated at $37^{\circ} \mathrm{C}$ for $15 \mathrm{~min}$ with $1 \mathrm{mg} / \mathrm{ml}$ of trypsin (Sigma). The enzymatic reaction was stopped by the addition of $50 \mu 1$ of acetic acid $(1 \mathrm{~mol} / \mathrm{l})$, and the sample applied to a Bio-Gel P-30 column.

\section{Results}

The elution patterns from Bio-Gel P-30 columns of both ${ }^{3} \mathrm{H}$-L-tryptophan-labelled proteins and proteins with specific immune reaction against a $\mathrm{C}$-terminal glucagon antiserum $(30 \mathrm{~K})$ are shown in Figure 1 . Figure 2 illustrates changes in the profiles as a function of the incubation time.

Conversely, we were unable to detect any radioactivity bound to the $30 \mathrm{~K}$ antiserum in the eluates of hepatocyte extracts. Tryptophan was incorporated into proteins of molecular weight $>40$ Kdaltons as indicated by the appearence of a considerable amount of immunoreactivity in the void volume (Fig. $2 \mathrm{~A}$ and $\mathrm{B}$ ). A second peak located close to the blue dextran volume was obtained at $2 \mathrm{~h}$ incubation (Fig $2 \mathrm{~A}$ ), disappearing thereafter. In addition, immunoreactivity peaks eluting in the regions of 14 and 3.5 Kdalton were very small at $2 \mathrm{~h}$ of incubation, but increased significantly with a longer incubation period (Fig $2 \mathrm{~B}$ ). When the labelled immunoreactive material was fractionated, using chromatographic columns equilibrated with urea $(7 \mathrm{~mol} / \mathrm{l})$ or guanidine $\mathrm{HCl}(6 \mathrm{~mol} / 1)$, the elution pattern was similar to that obtained with glycine buffer, indicating the absence of non-covalent interactions between the different immunoreactive components (Fig.3). When chromatographic fractionation was carried out in the presence of urea $(7 \mathrm{~mol} / \mathrm{l})$ or guanidine $\mathrm{HCl}(6 \mathrm{~mol} / \mathrm{l})$, a marked increase of immunoreactive peaks was observed as a consequence of prolonged incubation (Fig. 3).

To determine the molecular weight of the immunoreactive material eluting before the $3.5 \mathrm{Kdalton}$ peak, aliquots of the extracted cells incubated with ${ }^{3} \mathrm{H}-\mathrm{L}$ tryptophan for 2 or $4 \mathrm{~h}$, were immunoprecipitated with $30 \mathrm{~K}$ antiserum and the resulting sediment was solubilised with $\mathrm{HCl}(0.1 \mathrm{~mol} / \mathrm{l})$ and subjected to sodium dodecyl sulphate PAGE (Fig.4). Under these experimental conditions, the large immunoreactive material migrated with $R_{f}$ of $0.33,0.48,0.57$ and 0.80 , corresponding to molecular weights of $125.8,63.1,42.6$ and 14.4 Kdaltons, respectively. In addition, the radioactivity incorporated in each of these four polypeptides in-

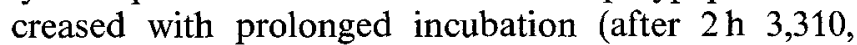
2,340, 1,944 and $487 \mathrm{cpm}$ in the 125.8, 63.1, 42.6 and 14.4 Kdalton components, respectively, and after $4 \mathrm{~h}$ $6,831,4,322,5,356$ and $4,432 \mathrm{cpm}$ in the same polypeptides). It is interesting to note that as the period of incubation increased incorporation of radioactivity was greater in polypeptides of smaller molecular weight. 

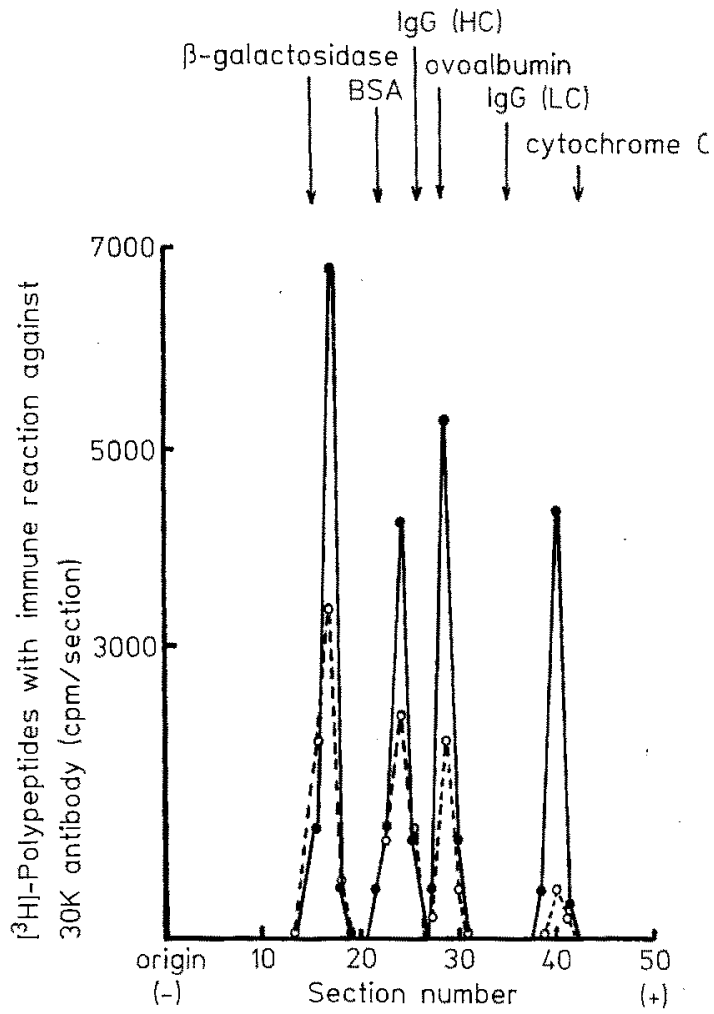

Fig. 4. Sodium dodecyl sulphate polyacrylamide gel electrophoresis of ${ }^{3} \mathrm{H}$-L-polypeptides with specific immune reaction with a $\mathrm{C}$-terminal glucagon antiserum $(30 \mathrm{~K})$ from isolated cells of rat submaxillary glands. Electrophoretic profiles after $2 \mathrm{~h}\left(\mathrm{O}-\mathrm{O}^{\mathrm{O}}\right)$ and $4 \mathrm{~h}($ are representative of four different experiments. BSA: bovine serum albumin; IgG (HC) and IgG (LC): immunoglobulin G, heavy and light chains

When the larger peak (Fig. 2 B) was treated with trypsin $(1 \mu \mathrm{g} / \mathrm{ml})$ for $20 \mathrm{~min}$ at $37^{\circ} \mathrm{C}$ and re-chromatographied on the same Bio-Gel P-30 column, a 4.5-fold increase in glucagon immunoreactivity was associated with a molecule having the molecular weight of glucagon (Fig. 2C). A highly significant loss of immunoreactivity occurred in the larger peptide as a consequence of this proteolytic transformation.

If glucagon-associated immunoreactivity is derived via a precursor, a pulse-chase incubation of isolated submaxillary gland cells would result in decreased labelling in the precursor region, but continued labelling of glucagon. Chasing of the immunoreactivity from the presumed precursor region was tested with unlabelled tryptophan and after cycloheximide-treatment of isolated cells. In both cases, the pulse periods were $2 \mathrm{~h}$ and the chase period involved an additional $2 \mathrm{~h}$ of incubation in the presence of unlabelled tryptophan or cycloheximide. The results presented in Figures 5 and 6 suggest that the depletion of immunoreactivity in the largest molecule, after treatment with cycloheximide or unlabelled tryptophan, can be accounted for by transfer of immunoreactivity to the glucagon molecule. The addition of cycloheximide, an inhibitor of protein synthesis, markedly inhibited tryptophan incorporation into the proteins of the precursor region, thus implicating the ribosomes as the cellular site of synthesis [14].

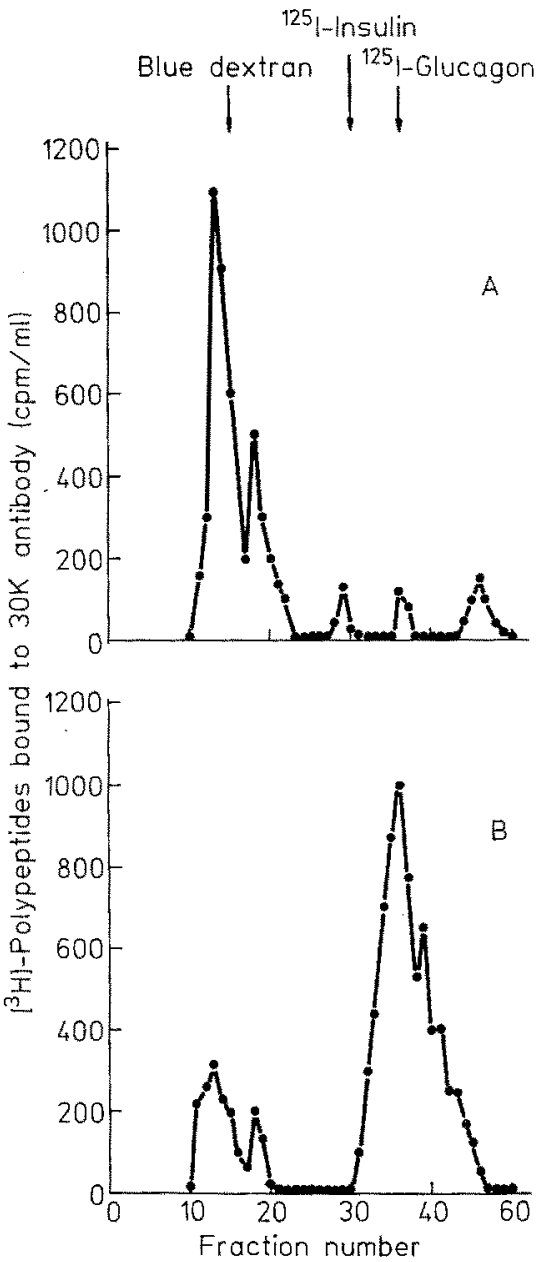

Fig. 5A and B. Gel filtration profiles of ${ }^{3} \mathrm{H}$-L-polypeptides showing specific immune reaction with a C-terminal glucagon antiserum $(30 \mathrm{~K})$ from rat submaxillary gland-isolated cells treated with cycloheximide. A Gel filtration profile after a 2 -h pulse period with ${ }^{3} \mathrm{H}-\mathrm{L}$ tryptophan. B Gel filtration profile after a 2 -h pulse period with ${ }^{3} \mathrm{H}-\mathrm{L}$ tryptophan and then a 2 -h period of cycloheximide-treatment. Chromatographic profiles are representative of three different experiments using the same Bio-Gel P-30 column

\section{Discussion}

By previous studies we know that the rat salivary gland has significant amounts of a polypeptide with the same physicochemical, immunological and biological properties as pancreatic glucagon $[3,5,12,15]$. In addition, when isolated cells of this gland are incubated with ${ }^{3} \mathrm{H}$ L-tryptophan, a radioactive polypeptide of $3.5 \mathrm{Kdal}-$ tons is immunoprecipitated with a C-terminal glucagon antiserum $(30 \mathrm{~K})$; suggesting that the salivary gland represents a source for synthesis of extrapancreatic glucagon rather than an organ that stores this hormone. In support of these findings, Hojvat et al. [16] found peroxidase-glucagon antiserum complexes located in the basilar portion of larger ductular cells in rat submaxillary glands. In this study, we present evidence that glucagon is actively synthesised by rat submaxillary gland cells via intermediates of higher molecular weight. Peptides larger than glucagon, which react with antiglucagon sera, have been detected in glucagonomas [17] and 


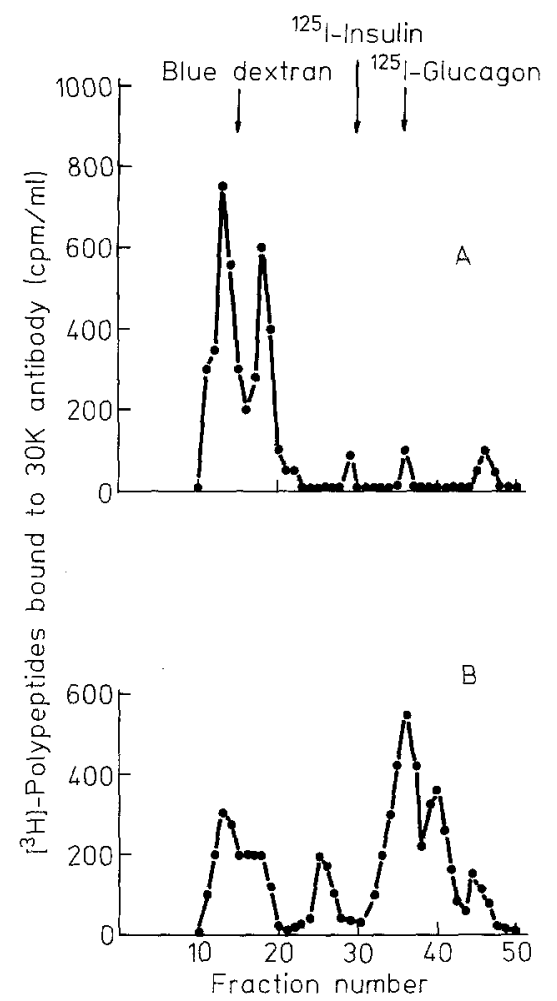

Fig. 6A and B. Pulse-chase incubation of rat submaxillary gland-isolated cells with unlabelled tryptophan. Radioactive peptides show specific immune reaction with a C-terminal glucagon antiserum $(30 \mathrm{~K})$. A Gel filtration profile after a 2 -h pulse period with ${ }^{3} \mathrm{H}-\mathrm{L}-$ tryptophan. B Gel filtration profile after a 2 -h pulse with ${ }^{3} \mathrm{H}$-L-tryptophan and then a 2 -h chase with unlabelled tryptophan. Chromatographic profiles are representative of three different experiments using the same Bio-Gel P-30 column

pancreatic islets from several animal species [18]. Gel filtration of the acid alcohol extracts of these tissues disclosed three or four peaks of immunoreactivity [18-21] and the molecular sizes reported for these large glucagon immunoreactive peptides are from 4.5 to $160 \mathrm{Kdal}-$ tons. In addition, four immunoreactive fractions have been observed in the plasma of normal or de-pancreatized animals [22], suggesting that they are derived from pancreatic or extrapancreatic sources. In addition, incorporation of ${ }^{3} \mathrm{H}$-L-tryptophan into peptides larger than glucagon has been detected in pancreatic islets from several animal species [14, 23-25]. Our results also indicate that the incorporation of radioactive tryptophan into polypeptides of smaller molecular weight increases with the period of incubation, more than $2 \mathrm{~h}$ of incubation being necessary to obtain a significant amount of radioactive immunoreactive glucagon. Delayed incorporation of labelled amino-acids into pancreatic precursors and glucagon has also been observed; thus the appearance of label in $9 \mathrm{~K}$ polypeptide occurs after $2 \mathrm{~h}$ in angler fish islets [26] and after $4 \mathrm{~h}$ in the perfused rat pancreas [27]. Appearance of the label in glucagon takes more than $4 \mathrm{~h}$ in the perfused rat pancreas [27] and more than 6 days in cultured guinea pig islets [28]. Although the nature of the very large immunoreactive glucagon and its possible rôle in glucagon production is not well understood, Tung and Zerega [23] have described the incorporation of ${ }^{3} \mathrm{H}$-L-tryptophan into a $69 \mathrm{~K}$ polypeptide by pigeon islets, which retains its size after treatment with dissociative agents and contains peptides of molecular size and chromatographic properties identical to porcine glucagon. We have found that isolated cells of the rat submaxillary glands incorporate ${ }^{3} \mathrm{H}$-L-tryptophan into large polypeptides, which are related to glucagon because of their specific immunoprecipitation with a C-terminal glucagon antiserum. Larger immunoreactive glucagon in the submaxillary gland-isolated cells, could be considered a polymer or a degradation product of glucagon. However there are several arguments against such an hypothesis: (1) tryptophan labelling appears in the precursor region long before immunoreactivity is detected in the glucagon region and the incorporation rate increases with the period of incubation; (2) the molecule is stable since treatment with urea $(7 \mathrm{~mol} / \mathrm{l})$, guanidine hydrochloride $(6 \mathrm{~mol} / \mathrm{l})$ and mercapto-ethanol failed to alter the gel filtration elution volume, indicating the absence of noncovalent interactions of disulphide bonding between them; and (3) immunoreactivity is significantly increased after tryptic digestion, mainly in a peptide of the same molecular weight as glucagon.

If a precursor-product relationship exists between the larger protein and glucagon, trypsinization may release glucagon. In fact, when the larger peak was treated with trypsin, a 4.5-fold increase in glucagon immunoreactivity was associated with a molecule having the molecular weight of glucagon. These results suggest that the largest peptide contains at least one peptide segment into which ${ }^{3} \mathrm{H}$-L-tryptophan can be incorporated, with an antigenicity, and size similar to that of pancreatic glucagon. Similarly, Valverde et al. [29] have reported that tryptic digestion of the big plasma immunoreactive glucagon (molecular size 150,000 daltons) generates a net increase in glucagonsized immunoreactivity. In addition, we present evidence that glucagon-associated immunoreactivity is derived via a precursor, since pulse-chase incubations of isolated submaxillary gland-cells with unlabelled tryptophan or with cycloheximide results in decreased labelling in the precursor region but continued labelling of glucagon. Cycloheximide, an inhibitor of protein synthesis, markedly inhibits tryptophan incorporation into the proteins of the precursor region, thus implicating the ribosomes as the cellular site of synthesis [14].

Our results suggest that rat submaxillary gland-cells actively synthesise glucagon and that a precursor-product mechanism is involved in this process. However, on the basis of results obtained with cell-free translation and cDNA sequencing experiments, it is not accepted that large glucagon immunoreactivity greater than $20 \mathrm{~K}$ serves as a biosynthetic precursor of glucagon [30]. Therefore, it has been suggested that very large immunoreactive components represent smaller glucagoncontaining peptides bound non-covalently to larger components [30]. Nevertheless, it has been reported by 
Shield et al. [31] that cell-free pro-glucagon molecules underwent a post-translational increase in size in the presence of microsomal membranes. Also Tung et al. [32] have described large glucagon immunoreactive peptides of 45 and $10 \mathrm{~K}$, extracted from fetal bovine pancreas that react specifically with lectin-sepharoses, suggesting that large glucagon immunoreactivity may be glycosylated as in the case of calcitonin or ACTH/ endorphin/ $\beta$-lipotropin [33, 34].

Acknowledgements. The authors wish to thank to Mrs. A.García Ledesma for secretarial assistance in preparing this manuscript. The work was supported by grants from the Comision Asesora de Investigación Científica y Tećnica and the Fundación Rodriguez Pascual, Spain. Part of this work was presented at the 17th Annual Meeting of the European Association for the Study of Diabetes, Amsterdam, 1981.

\section{References}

1. Bryant MG, Polack M, Modlin I, Bloom SR, Albuquerque RH, Pearse AGE (1976) Possible dual role for vasoactive intestinal peptide as gastrointestinal hormone and neurotransmitter substance. Lancet 1: 991-993

2. Pearse AGE, Polack JM (1975) Immunócytochemical localization of sustance $\mathrm{P}$ in mammalian intestine. Histochemistry 41 : 373-375

3. Silverman H, Dunbar JC (1974) The submaxillary gland as a possible source of glucagon. Bull. Sinai Hosp. Detroit 22: 192-193

4. Sasaki H, Rubalcava B, Baetens D, Blázquez E, Srikant CB, Orci L, Unger RH (1975) Identification of glucagon in the gastrointestinal tract. J Clin Invest 56: 135-145

5. Pérez Castillo A, Blázquez E (1980) Tissue distribution of glucagon, glucagon-like immunoreactivity, and insulin in the rat. Am J Physiol 238: E258-E266

6. Conlon JM (1981) Molecular forms of the glucagon-like polypeptides IRG and GLI in tissues and plasma. In: Unger RH, Orci $\mathrm{L}$ (eds) Glucagon. Elsevier North Holland, New York, pp 56-75

7. Baetens D, Rufener C, Srikant CB, Dobbs RE, Unger RH, Orci L (1976) Identification of glucagon-producing cells (A-celis) in dog gastric mucosa. J Cell Biol 69: 455-464

8. Muñoz-Barragan L, Rufener C, Srikant CB, Dobbs RE, Shanon Jr WA, Baetens D, Unger RH (1977) Immunocytochemical evidence for glucagon containing cells in the human stomach. Horm Metab Res 9: 37-39

9. Muñoz-Barragan L, Blázquez E, Patton GS, Orci L, Dobbs RE, Unger RH (1976) Gastric A-cell function in normal dogs. Am J Physiol 231: 1057-1061

10. Blázquez E, Muñoz-Barragan L, Patton GS, Orci L, Dobbs RE, Unger RH (1976) Gastric A-cell function in insulin-deprived depancreatized dogs. Endocrinology 99: 1182-1188

11. Blázquez E, Muñoz-Barragan L, Patton GS, Dobbs RE, Unger RH (1977) Demonstration of gastric glucagon hypersecretion of insulin-deprived alloxan-diabetic dogs. J Lab Clin Med 89: 971-977

12. Pérez Castillo A, Blázquez E (1980) Synthesis and release of glucagon by human salivary glands. Diabetologia 19: 123-129

13. Laemmli UK (1970) Cleavage of structural proteins during the assembly of the head of bacteriophage $T_{4}$. Nature (Lond) 227: 680-685

14. Noe BD, Baste CA, Bauer GE (1977) Studies on proinsulin and proglucagon biosynthesis and conversion at the subcellular level. II. Distribution of radioactive peptide hormones and hormone precursors in subcellular fractions after pulse and pulse-chase incubation of islet tissue. J Cell Biol 74: 589-604

15. Bathena SJ, Smith SS, Voyles NR, Penhos JP, Recant L (1977) Studies on submaxillary gland immunoreactive glucagon. Biochem Biophys Res Commun 74: 1574-1581
16. Hojvat S, Kirsteins L, Kisla J, Paloyan V, Lawrence AM (1977) Immunoreactive glucagon in the salivary glands of man and animals. In: Foá PP, Bajaj JS, Foà NL (eds) Glucagon: its role in physiology and clinical medicine. Springer, New York, pp 143-155

17. Weir GC, Horton ES, Aoki TT, Slovik D, Jaspan J, Rubenstein AH (1977) Secretion by glucagonomas of a possible glucagon precursor. J Clin Invest 59: 325-330

18. Rigopoulou D, Valverde I, Marco J, Faloona JR, Unger RH (1970) Large glucagon immunoreactivity in extracts of pancreas. J Biol Chem 278: 496-501

19. Tung AK (1973) Biosynthesis of avian glucagon: evidence for a possible high molecular weight biosynthetic intermediate. Horm Metab Res 5: 416-424

20. Trakatellis AC, Tada K, Yamaji K, Gardiki-Kouidou P (1975) Isolation and partial characterization of angler fish proglucagon. Biochemistry 14: 1559-1563

21. Tager HS, Markese J (1979) Intestinal and glucagon-like polypeptides. Evidence for identity of higher molecular weight forms. $J$ Biol Chem 254: 2229-2233

22. Valverde I, Dobbs RE, Unger RH (1975) Heterogeneity of plasma glucagon immunoreactivity in normal, depancreatized and alloxan diabetic dogs. Metabolism 24: 1021-1028

23. Tung AK, Zerega $F$ (1971) Biosynthesis of glucagon in isolated pigeon islets. Biochem Biophys Res Commun 45: 387-395

24. Noe BD, Bauer GE (1971) Evidence of glucagon biosynthesis involving a protein intermediate in islets of the angler fish. Endocrinology 89: 642-651

25. Patzelt C, Tager HS, Carroll RJ, Steiner DF (1979) Identification and processing of glucagon in pancreatic islets. Nature 282: 260-266

26. Noe BG, Bauer GE (1975) Evidence for sequential metabolic cleavage of proglucagon to glucagon in glucagon biosynthesis. Endocrinology 97: 868-877

27. O'Connor KJ, Gay A, Lazarus NR (1973) The biosynthesis of glucagon in perfused rat pancreas. Biochem J 134: 473-480

28. Hellerström C, Howell SL, Edwards JC, Andersson A, Östenson CG (1974) Biosynthesis of glucagon in isolated pancreatic islets of guinea pigs. Biochem $\mathrm{J} 140$ : 13-23

29. Valverde I, Villanueva ML, Lozano I, Marco J (1974) Presence of glucagon immunoreactivity in the globulin fraction of human plasma ("big plasma glucagon") J Clin Endocrinol Metab 39: $1020-1028$

30. Noe BD, Fletcher DJ, Bauer GE (1981) Biosynthesis of glucagon and somatostatin. In: Cooperstein SJ, Watkins D (eds.) The islets of Langerhans: biochemistry, physiology and pathology. Academic Press, New York, pp 189-224

31. Shields D, Warren TG, Roth SE, Brenner MJ (1981) Cell-free synthesis and processing of multiple precursors to glucagon. Nature 289: $511-514$

32. Tung AK, Cockburn E, Sin KP (1982) Glycoprotein-like large glucagon immunoreactive species in extracts of the fetal bovine pancreas. Diabetes 31: 1002-1005

33. Eipper BA, Mains RE (1980) Structure and biosynthesis of proadrencorticotrophin/endorphin and related peptides. Endocrinol Rev 1: 1-27

34. O'Neal JA, Birbaum RS, Jacobson A, Roos BA (1981) A carbohydrate-containing form of immunoreactive calcitonin in transplantable rat medullary thyroid carcinoma. Encodrinology 108: $1098-1100$

Received: 20 October 1983

and in revised form: 20 July 1984

Professor E. Blazquez

Departamento de Fisiologia y Bioquimica

Facultad de Medicina

Universidad de Salamanca

Salamanca

Spain 